\title{
Safe Foods for Celiac People
}

\author{
Carlos Osella, Maria de La Torre, Hugo Sánchez* \\ Instituto de Tecnología de Alimentos, Facultad de Ingeniería Química, Universidad Nacional del Litoral, \\ Santa Fe, Argentina \\ Email: hsanchez@fiq.unl.edu.ar
}

Received 28 November 2013; revised 28 December 2013; accepted 6 January 2014

Copyright (C) 2014 by authors and Scientific Research Publishing Inc.

This work is licensed under the Creative Commons Attribution International License (CC BY). http://creativecommons.org/licenses/by/4.0/

(c) (i) Open Access

\begin{abstract}
Celiac Disease is a chronic entheropathy produced by gluten intolerance, more precisely to certain proteins called prolamines, which causes atrophy of intestinal villi, malabsorption and clinical symptoms that can appear in both childhood and adulthood. This pathogeny, results from the interaction of genetic, immunologic and environmental factors, which produce the lesions on the mucosa of the proximal small intestine. It is important to estimate the maximum gluten content that could be present in supposedly "gluten-free" foods, a limit of $20 \mathrm{mg} / \mathrm{Kg}$ is admitted. Rice flour, sorghum flour, starches, hydrocolloids, soy flour and dairy products are analyzed for carrying out the manufacture of gluten-free products, such as bread, noodles and others.
\end{abstract}

\section{Keywords}

Celiac Disease; Gluten-Free Products; Raw Materials for Celiac People

\section{Introduction to Celiac Disease}

Celiac Disease (CD) is a chronic entheropathy produced by gluten intolerance, more precisely to certain proteins called prolamines, which causes atrophy of intestinal villi, malabsorption and clinical symptoms that can appear in both childhood and adulthood [1] [2]. It occurs in about 1\% of European people [3]. These proteins are found in wheat, oat, barley and rye (TACC, in Spanish). The toxic fractions adopt different names, depending on the cereal: gliadin in wheat, avidin in oat, secalin in rye and hordein in barley [4] [5]. Prolamins of wheat, barley and rye are characterised by high proline content. These proteins, the main constituents of gluten, contain toxic sequences that can trigger celiac disease. Huang et al. [6] suggested that a particular peptide, consisting of 33 aminoacids, including 13 proline residues, is involved in the toxicity. This peptide, the 33-mer, is often used as a model in coeliac disease-related studies.

Celiac disease may be associated with autoimmune diseases. Most celiac patients under risk of developing an

${ }^{*}$ Corresponding author. 
autoimmune disease are diagnosed in the early stages of their life and have a family history of autoimmunity. In these cases, the gluten-free diet has a protective . Based on this, the celiac disease can be said to be a genetic-based autoimmune enteropathy [8], characterised by variable degrees of damage in the intestinal mucosa. This condition appears in genetically susceptible individuals who have been exposed to gluten consumption [9]. Medical research has produced an extensive list of epitopes intrinsically present in wheat, rye and barley that are recognized by $\mathrm{T}$ cells from $\mathrm{CD}$ patients [10].

Three components are known to interact in the pathogeny: 1) Toxicity of certain cereals: the disorder occurs only after prolonged exposition to gluten protein present in wheat, oat, barley and rye, 2) Genetic predisposition: about $2 \%$ to $5 \%$ of first degree relatives suffer symptomatic enteropathy and up to $10 \%$ of them present asymptomatic injures in the small intestine mucosa, 3) Environmental factors: they are likely to affect the occurrence of this genetic predisposition [11]. The enzyme tissue transglutaminase (tTG) can play a significant role in the celiac disease pathogeny since it may result in a higher proliferative response of cells contributing to mucosa inflammation [12]. On the other hand, certain drugs can increase gluten susceptibility in some people with certain predisposition to developing the disease, as was observed in patients treated with $\alpha$ interferon [13]. Besides, intestinal infections could result in a transitory increase of small intestine permeability, thus inducing the tissue transglutaminase release. As shown in recent studies, a high frequency of rotavirus infections can increase the risk of celiac disease in genetically predisposed children [14].

The immune response to gluten produces villi atrophy, crypt hyperplasia and surface damage in the small intestine. The injury is highest in the proximal portion of the small intestine and extends up to a variable distance in a distal sense. This last observation accounts for the variability in the degree of symptoms and signals of malabsorption between people with gluten sensitive enteropathy. The decrease in the small intestine area and the relative increase in immature epithelial cells determine a decreased absorption and digestion capacity [11].

In conclusion, the pathogeny results from the interaction of genetic, immunologic and environmental factors [15], which produces lesions in the mucosa of the proximal small intestine, thereby leading to the intestinal villous atrophy (Figure 1). This, in turn, also causes defects in absorption and use of nutrients such as proteins, fats, carbohydrates, mineral salts and vitamins, and may lead to a severe malnutrition condition [16].

According to clinical manifestations, CD is classified in: 1) Symptomatic or Classical, which includes some degree of malabsorption of nutrients and is generally more frequent during childhood, 2) Oligosymptomatic or monosymptomatic (or silent), in which the gastrointestinal symptomatology may have low intensity or the patient may present non-gastrointestinal symptoms. This type occurs mainly in older children and adults and appears in different forms: Potential: it applies to those asymptomatic patients having an increased count of intraepithelial lymphocytes in the jejunal mucosa. Forty one percent of the first degree relatives of celiac people would belong to this classification, genetic load and environmental factors such as amount of gluten in the diet and recurrent infections being critical factors in the evolution towards more severe forms of enteropathy [17]. Latent: it occurs in genetically susceptible individuals, though with no clinical or histological manifestations [1] [17]. Silent: it is characterized by the presence of typical histological injures, antibodies transglutaminase and

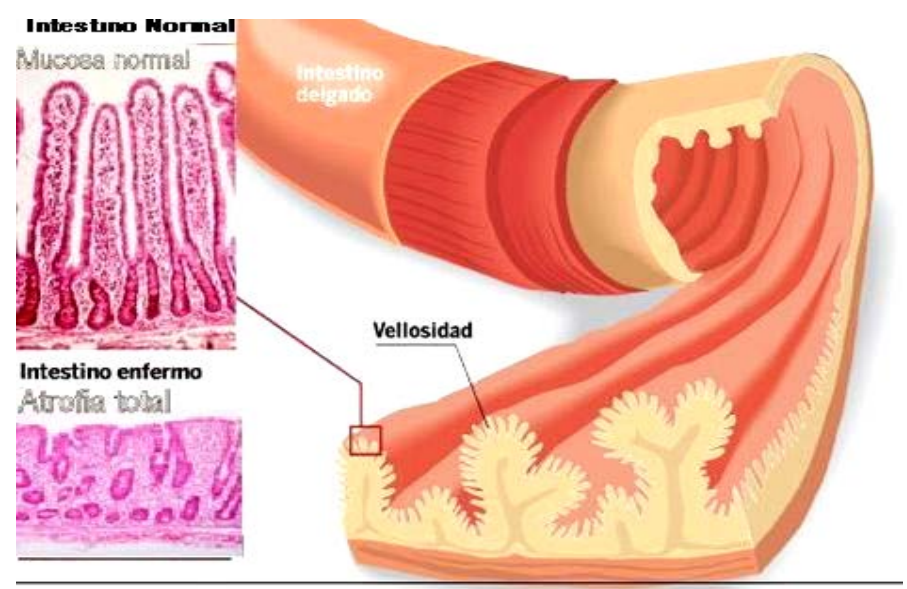

Figure 1. Cross section of the small intestine. Comparison of normal and atrophic intestinal villi. 
specific genotypes in asymptomatic or oligosymptomatic individuals, though with atypical symptomatology [1]. Active: it appears with typical symptomatology, malabsorption, chronic diarrhea, steatorrhea or constipation. However, there are cases without malabsorption, with even only abdominal specific symptoms [1].

Since CD symptoms are very varied, people may experience diarrhea and vomits, but also growth delay, abdominal distension, decalcification, which in turn can lead to spontaneous fractures, changes in tooth enamel, recurrent ulcers in the mouth, skin disorders such as dermatitis herpetiformis, neurologic disorders, depression, anemia, hemorrhages and reproductive disorders like sterility and repetitive abortions [4].

In the classical type, gastrointestinal symptoms predominate, mainly in children, and appear after a time of exposition to gluten, in breast-fed infants (8 and 24 months of age). Diarrheic, often steatorrheic stools, alternate with asymptomatic periods of days to weeks. There is progressive suppression of appetite, resulting in the subsequent deterioration in the nutritional status. At the onset of the disease, the physical exam does not usually show significant signals, the nutritional status appearing then compromised, as well as abdominal distension and muscular atrophy. Vomiting or constipation predominates in some cases, which may lead to an erroneous etiology and delayed diagnosis. Personality changes may also occur: the child may gradually become irritable or listless. The latter pattern appears at school age and is generally less symptomatic than in the young child; it can even be monosymptomatic, as is the case of anemia not responding to iron treatment [18].

Patients with severe and non treated disease may develop short stature, delayed puberty, iron and folate deficiency, with anemia and rickets. The atypical celiac disease is generally observed in older children or adolescents, who often show no signs of malabsorption. It may also appear with recurrent abdominal pain, aphthous stomatitis, arthralgia, changes in tooth enamel and poor school performance [19].

Without a treatment, symptoms may persist throughout childhood, though they can usually decrease or disappear completely during adolescence and appear again in the early adulthood, between 30 and 40 years. About $20 \%$ of affected people are older than 60 years. However, many of them have no history of symptoms, which suggests that the celiac disease can develop in adulthood [19].

Diarrhea in celiac adults can have a gradual or sudden onset. Pregnancy, gastroenteritis or gastrointestinal surgeries could be the trigger for the symptoms development [20]. It is an infrequent situation, representing the severe decompensation of the disease. It is characterized by a severe general involvement and profuse diarrhea, with intense electrolyte imbalance, where tetany, edema from hypoproteinemia, bleeding disorders due to vitamin K deficit and in some cases shock and sensory involvement may occur [18]. Two kinds of symptoms may be distinguished: 1) Gastrointestinal symptoms, among which diarrhea, flatulence, weight loss, fatigue and recurrent abdominal pain may be found. Diarrhea can occur with up to 10 watery (or non watery) stools. Dehydration due to electrolyte loss is also possible. The extent of weight loss depends on the severity and extent of the disease on the intestinal mucosa and on the patient's ability to compensate malabsorption by increasing the intake. Weakness, laxity and fatigue are related to malnutrition in general. Muscle weakness may be associated with potassium loss in feces. Intense abdominal pain is not common, 2) Extraintestinal symptoms; approximately $50 \%$ of patients do not present a clinically significant diarrhea. Manifestations of these symptoms may be: Hematopoietic: anemia is the most common presentation due to alteration in iron and folic acid absorption in the proximal intestine there can be purple, gastrointestinal, nasal and renal bleeding, by alteration in vitamin $\mathrm{K}$ absorption. Deformed erythrocytes and splenic atrophy in 50\% of patients are also observed [19], Skeletal: osteopenia appears due to calcium and vitamin D malabsorption, as well as by calcium intake decrease as a consequence, also, of lactose intolerance. Also genre, lack of physical activity and malnutrition can contribute to this condition. It responds to gluten-free diet, with gradual bone restoration in two years, for which early treatment is essential [1], Neurologic: it occurs in $10 \%$ of patients, mainly as cerebellar ataxia (10\% - 16\%), peripheral neuropathy (49\%), epilepsy, dementia and depression. Depression and psychiatric symptoms are common complications in about one third of patients, which could be due mainly to vitamin B6 deficit [1]. There can be night blindness, attributable to vitamin A deficiency, and cases of epilepsy and delayed memory [19], Cutaneous: there is a frequent association with dermatitis herpetiformis. Papulovesicular and pruritic lesions can improve in weeks or months with a gluten-free diet, associated to the use of dapsone. There can also be psoriasis, alopecia and aphthous stomatitis [1].

Epidemiologic studies have shown that the prevalence of celiac disease has been significantly underestimated [21]. Although intestinal biopsia is still the best diagnosis procedure for this disease [22], the use of serologic tests to detect antigliadin antibodies has substantially increased the detection of affected individuals. There is a worldwide prevalence of 1:3345 by means of clinic diagnosis and of 1:266 by means of serologic screening [21]. 
Once the disease has been diagnosed, the treatment consists in abandoning the consumption of wheat, oat, barley and rye (TACC, in Spanish) for the rest of one's life; that is, a diet based on TACC-free, or "gluten-free" food, must be adopted [23]-[26]. Nowadays, some researchers have raised the idea whether the gluten-free diet for celiac patients should be lifetime, for which adult celiac patients, to whom the disease had been detected during childhood, were evaluated, to study if a lag period of the disease could occur with a normal diet. A small proportion of all celiac patients diagnosed during infancy (probably $<10 \%$ ) would develop gluten tolerance, which could be non permanent and, though remaining asymptomatic, they would require periodic serologic and histologic controls. For this small number of patients, it could be said that they do not require a lifetime glutenfree diet [26]. Some patients suffer from refractary celiac disease, that is, they do not respond completely to a gluten-free diet [27]-[29].

The nutritional status of people newly diagnosed with celiac disease depends on the period of time they have lived with the disease subdiagnosed, on the extent of injury to the gastrointestinal tract and on the degree of malabsorption. When they are diagnosed, some patients show a substantial weight loss, anemia and evidence of vitamin and mineral deficit [21]. Patients showing nutritional deficiencies could, either temporally or during a longer period, require supplementation of their diets with vitamins, minerals and proteins to correct deficiencies and restore nutrient reserves; recent studies, however, have not considered specifically the efficacy of extra intake of nutrients in the celiac disease treatment [30]. Also patient education and maintenance of a gluten-free diet is of utmost importance. Patients failing to maintain a gluten-free diet reflect misinformation about the restrictive nature of the diet to be followed [30]. The ideal behaviour is for patients, doctors, nutritionists and support groups to work together and coordinately so as to appropriately inform recently diagnosed celiac disease patients about the diet to follow [30]-[32]. It is fundamental that patients be immediately derived to a nutritionist specialized in celiac disease to complete the nutritional status evaluation. Such experienced professional can advise patients about how complex gluten-free diet is, the adequate supplementation with vitamins and minerals, sources of hidden gluten, as well as plan a balanced diet, advise about buying food and reading the product's labels, eating out at a restaurant or travelling, counsel about the benefits of physical exercise and the importance of joining working groups. Patients need to integrate their gluten-free diet to their school, their work, as well as their family life [33].

\section{Gluten-Free Products}

It is important to estimate the maximum gluten content that could be present in supposedly "gluten-free" foods, even at a trace level. According to recent studies, a limit of $20 \mathrm{mg} / \mathrm{Kg}$ is admitted [34] [35]. The amount of tolerable gluten was observed to vary among celiac people. Besides, no evidence suggests a definite minimal gluten amount [36].

Despite the advantages of recent methods, the evaluation of food innocuity for celiac patients, based on gluten analysis by ELISA test, is not clear. Measurement standardization appears as the most difficult issue to be solved in gluten analysis. Although gliadin has been considered the best standard for measuring gluten, it cannot be an exact representation of food gluten in all cases since gluten composition varies between cereal species and varieties, and gliadin is present only in wheat. Moreover, the technological procedures used by food industry produce physical, chemical and enzymatic changes in foods, which can affect gluten solubility [37]. Using gliadin standard can also be underestimated on the grounds that it overlooks the glutenin fraction of gluten [38]. Glutenin peptides are known to be involved in the activation of certain mechanisms in celiac patients [39]. Being very insoluble, glutenins can persist during the transformation processes of foods where gliadins are removed [40]. Therefore, whether a gluten detection method is able to indicate food toxicity using only a gliadin standard is still under discussion [37].

Wheat meal-based products are massively consumed by population. Among them, bread and pasta occupy a paramount place worldwide [3] [41]. Unfortunately, the gluten-forming proteins are fundamental for the production of a great variety of foods, including pasta, which is generally made from durum wheat. Durum wheat proteins are characterized by a typical viscoelastic behavior that allows good networking of the matrix and optimal dough formation during the mixing and extrusion phases, and are also mostly responsible for the quality attributes of cooked pasta [42]. Among cereals considered suitable to be consumed by celiac population we can mention corn, rice, sorghum, as well as their starches, which have been studied as potential substitutes of wheat in celiac product formulation. 
Aiming at the production of bread and pasta of acceptable quality, ingredients able to add viscoelastic properties to the dough have been incorporated to the formulation. In the case of pasta, they contribute to al dente texture after cooking and, in the case of bread, to the retention of the gas produced during fermentation. This latter aspect is of utmost importance to form the structure that determines the final texture characteristic of bread. The use of hydrocoloids as hydroxypropylmethylcelullose, espina corona gum, xanthic gum, guar gum, gelatine and carboxymethylcelullose represents the most adequate alternative to imitate gluten in manufacturing gluten-free baked products [43]-[47]. It is worth mentioning that the products so manufactured show a very low protein content, so their fortification appears to be essential [25].

Given their high lysine content, soy proteins have the highest biological value within plant proteins. They can be found as flours, concentrates, isolates and texturized, but are suitable to meet human needs only if they have been properly processed.

On the other hand, researches using cheese whey protein concentrate (WPC) in pasta have been intensified [48]. The WPC-enriched end product has a high nutritional value due to the presence of the essential amino acids lysine, methionine and tryptophan. It is also considered an ideal supplement, mainly in pasta production, since it undergoes minimal denaturation during drying and the amino acid composition of pasta is not affected by cooking [49].

\section{Importance of the Raw Material}

\subsection{Rice Flour}

Rice is the main staple food for many countries, providing $20 \%$ of the food energy supply in the world. It is not only a significant source of energy but a good source of B vitamins (thiamine, riboflavin and niacin). According to its amino acid profile, rice has high contents of glutamic and aspartic acids, lysine being the limiting amino acid [50]. Due to its low prolamin content and hypoallergenic character, insipid taste, low sodium content and high content of easily digestible carbohydrates, it has become a cereal specially suitable not only to prepare gluten-free food but also special diets [51] [52]. However, it is known that bread made with both rice and any other cereal suitable for celiacs rarely has good acceptability. Since they lack viscoelastic properties, that is, those properties conferred only by gluten-forming proteins like those present in wheat, the flour of these cereals is incapable of forming continuous phase and dough structure when mixed with water and, consequently, good quality breads [53]. In order to achieve this acceptability, it is then necessary that gluten-free breads formulated with these cereals have quality characteristics similar to those made with wheat flour [44]. On the other hand, Athapol et al. [54], working with flours from different rice cultivars in the production of cracker type cookies for celiac people, found that the products were acceptable, though they tended to a decreased volume and an increased hardness due to the storage time of those cultivars. Sivaramakrishnan et al. [55] worked in a series of tests with either long or short grain rice, whose flours were then used in bread making with the addition of additives such as hydroxypropylmethylcellulose. When comparing the results obtained with wheat flour $(100 \%)$ and with wheat flour/rice flour (50 - 50), they found a significant improvement in the bread making properties and the crumb texture quality in the samples obtained with long-grain rice.

On the other hand, experiences have been made with gluten-free bread formulations, substituting one part of rice flour for pregelatinized rice flour, which led to the conclusion that the functionality of these flours depends on the cooking method used [56]. Among cereal cooking methods, extrusion cooking is preferred, since it offers a wide range of products with different functionalities depending on the degree of cooking attained [57]. In the case of rice, it will depend on the characteristics of the phenotype (amylose content, gelatinization temperature, etc) [58]-[60]. The degree of cooking of the extruded flour has been observed to increase with decreasing amylose content, which shows that the starch structure becomes more susceptible to the modifications caused by extrusion, a higher damage to the starch granular structure being observed during extrusion. This effect is verified through water solubility values and the amylographic characteristics, retrogradation consistency in particular. These two properties are inversely related [57] and are good indicators of the degree of cooking which means a certain degree of destruction of the crystalline and granular structures. That also means that higher solubility and lower retrogradation values correspond to higher cooking degree. Pedrosa Silva and El-Dash, [61] studied the behaviour of a gluten-free bread formulation when substituting part of a high amylose rice flour for the same flour previously precooked by extrusion, and observed an improvement in the bread quality. Sánchez et al. [24], in turn, when analyzing gluten-free bread making, considered the performance of seven rice genotypes whose 
flours were extruded and compared with the same flours without extrusion. Rice flours were extruded in the laboratory under $15 \%$ and $30 \%$ moisture levels. Bread making was carried out with the necessary hydration to maintain the creamed mixture at a constant consistency. Breads were evaluated by their sensory attributes by means of a trained panel. When completely substituting in the formulation the non-waxy rice flour without extrusion for the same $15 \%$ moisture extruded flour, the bread volume improved $22 \%$ and the crumb structure $120 \%$. These attributes, in turn, were significantly better when the substitution involved waxy genotype flours extruded both at $15 \%$ and $30 \%$ moisture, the increase being $41 \%$ and $142 \%$ for volume and crumb structure, respectively. Therefore, these waxy genotypes with extrusion treatment turned out to be particularly suitable for gluten-free bread making.

\subsection{Sorghum Flour}

Sorghum is a very important cereal in semiarid zones such as Africa (Nigeria, Sudan, Burkina Faso, Ethiopia), Asia (India, China), and in some other regions of Central and South America. It is thought that about $40 \%$ of the world production is intended for human consumption [62] [63]. Even though sorghum is the 5th largest crop produced worldwide and has been shown to be safe for people with celiac disease [64], the literature is relatively scarce compared to that of corn and rice in exploring sorghum for production of foods for Western markets [65]. On the other hand, developed countries are beginning to require sorghum for use in gluten-free foods [66] [67]. Sorghum grain colour ranges from white to dark shades of red and brown, through pale yellow, the most common colours being white, bronze and brown. The main protein fraction in the grain is prolamin (kafirin), comprising $50 \%$ of the protein, followed by glutelin. These proteins are hydrophobic, rich in proline, aspartic acid and glutamic acids, with low content in lysine. They can be mainly found in protein bodies and are affected by nitrogen fertilization. Glutelins are high molecular weight proteins located mainly in the endosperm protein matrix. Protein fractions rich in lysine predominate in the germ.

Keregero and Mtebe [68] have reported that breads made with wheat and sorghum with a maximum of $30 \%$ sorghum are acceptable. Taylor et al. [66], on the other hand, working with sorghum cultivars with different types of endosperm, normal and waxy, found that breads made with normal sorghum were acceptable, whereas those obtained with waxy sorghum were unacceptable since they presented big alveoli and unpleasant texture. These authors conclude that amylose plays a fundamental role since that retrogradation after cooling is a significant factor in crumb stabilization.

Schober et al. [62], studied the effect of cultivars working with nine hybrid sorghum cultivars and commercial sorghum flour. They used the extrusion process to standardize crumb consistency and a formulation based on sorghum flour and corn starch (70/30), salt, sugar and yeast, adding water (95\% - 120\%) to the sorghum flour/ corn starch mixture. Although the bread volume was not affected by the hybrid, important differences were found in the crumb structure and texture. Damaged starch amount also affected the crumb structure, so that with high damaged starch, the highest hardness grains resulted in lower quality crumb structure.

Schober et al. [69], reported a formulation with sorghum flour and potato starch (70/30) with 2\% hydroxypropylmethylcellulose, to which a $100 \%$ water amount with respect to sorghum flour/potato starch was added. As process variable, acid $\mathrm{pH}$ fermentation was carried out, which decreased the trend to form large holes in the crumb [66], in turn, claim that higher levels of water produce a beating instead of dough, which is desirable to better dissolve all the particles. Gas bubbles formed during beating and fermentation are surrounded by a liquid film stabilizing the interphase, while tensoactive substances like polar liquids, soluble proteins and soluble pentosans including bread additives, emulsifiers, hydrocolloids or soy protein isolate can stabilize the liquid films around the gas bubbles.

The addition of starches, either pure or pregelatinized, to sorghum flour, also affects bread quality positively in the bread making process. This can be simply a dilution effect, that is, endosperm and bran particles in sorghum flour are diluted by the starch added. Any bran or endosperm particles are considered to disturb starch gel uniformity and interfere with the liquid particles around gas bubbles. Consequently, gluten-free breads, containing integral cereals, have lower volume than starch-added breads.

\subsection{Starches}

Starch is perhaps the most important natural existing polymer and the greatest source of energy obtained from 
certain plants. It is found in cereal seeds (corn, wheat, rice, and rye), tubers (potato), roots (cassava, sweet potato), legume seeds and fruits [70].

Starch properties such as amylose and amylopectin content, gelatinization temperature, gel consistency and/or texture, thermal properties, etc., allow it being used properly in food industry as stabilizer, filling agent, adhesive, binder, film former, foam stabilizer, gelifier, humectant and thickener [71]. Starch functional properties, such as solubility, water retention capacity, swelling, retrogradation, enzymatic digestibility, emulsifying capacity, etc. depend mainly on amylose/amylopectin ratio.

During the hydrothermal treatment, starch undergoes a series of changes that will affect its structure, through three important stages: gelatinization, gelification and retrogradation, which result in swelling, hydration, fusion and rupture of starch grain [70]. If a starch shows high swelling power and high solubility, it implies a low association force among granules. The swelling power of cereal starches is more limited than that observed in tuber starches. As regards water absorption capacity, it depends directly on the type of starch, being higher in tuber starches than in cereal ones, though it also depends on the amylose/amylopectin ratio and the grain size and shape.

Cassava starch gelatinizes approximately at the same temperature as corn starch $\left(62^{\circ} \mathrm{C}-73^{\circ} \mathrm{C}\right)$ and the amylographic peak is reached rapidly, which implies that it is an easily cooked starch. Although the viscosity is initially high, it falls abruptly with the continuous beating at a temperature above $90^{\circ} \mathrm{C}$, and the gel is not formed with the subsequent cooling. The low retrogradation properties of cassava starch can be used in many food products. It is resistant to the freezing process, thus decreasing water exudation or sineresis, which causes dough structure deterioration. Although it is used mainly as it is, that is, as native starch, it is also modified by means of different treatments to improve its properties of consistency, viscosity, stability to $\mathrm{pH}$ and temperature changes, gelification and dispersion, so that it can be used in different commercial applications [70]. Pérez [72], produced pasta with wheat/cassava compound flours, substituting up to $20 \%$ wheat flour for cassava flour, and obtaining pasta with a good response to cooking test and a satisfactory texture, which was accepted by the evaluation panel. Besides, the pasta color was superior to that of similar pasta found in the market.

As regards corn starch, it shows a rapid increase in viscosity after gelatinization, until it reaches a maximum point. Viscosity decreases gradually as temperature is kept constant and then it has a very strong increase while cooling and retrograding. Native starches show certain limitations for industrial use. Therefore, they are modified to improve their functional properties, so that they can be used in a wide range of industrial applications. In this way, modified starches become products of higher added value [70]. Pregelatinized starches are useful when it is required that the product can be reconstituted in cold water. The starch grain structure is broken when cooking the native starch and subsequent drying it in rotatory drums, which allows it being used in fast foods, fillings and sauces [70].

Sabbatini [73], found a marked difference in dough machinability and sensory evaluation when spaghetti was made with native starch and with pregelatinized starch. The integration of components turned out to be difficult with the former, which resulted in dry and brittle pasta. Instead, no such problems occurred when using the pregelatinized starch, with homogeneous, wet and non-sticky dough being obtained, which made the lamination process easier. As regards sensory evaluation, spaghetti were scored as soft and with a tendency to fall apart when using native corn starch, whereas they were qualified as having a smooth and soft to palate surface, and an "al dente" chewiness, when pregelatinized corn starch was used.

On the other hand Barrios et al. [74], found native starches unable to play a particular role, being then convenient to modify them so as to develop suitable properties to meet specific purposes, and hence diversify their use even more. Aristizábal and Sánchez [70], in turn, stated that starch modification allows enhancing or inhibiting properties such as consistency, binding power, stability to $\mathrm{pH}$ and temperature changes, as well as improving its gelification, dispersion or fluidity.

\subsection{Hydrocolloids}

Making gluten-free pasta is a difficult task, since gluten contributes to form a strong protein network which prevents the pasta from dissolving during cooking. Though gluten-free flours can be used, they need that the traditional manufacturing process be modified [75]. In order to substitute gluten in gluten-free formulations, hydrocolloids are used, which are incorporated for a variety of purposes, that is, as gelifiers or to optimize texture and water retention in the products [76]-[79]. They are also used as additives with the aim of reproducing the gluten 
viscoelastic properties [80]. These hydrocolloids contain water soluble polysaccharides with a varied chemical structure which confer them certain functional properties so they can be applied appropriately [81]. Sánchez et al. [23], developed a formula for gluten-free bread, varying, among other important aspects, the hydrocoloid type to be used (Figure 2). They found hydroxypropylmethylcellulose to have the best results, with excellent values for bread volume, crumb texture and sensory attributes.

On the other hand [82], working with varying proportions of corn starch/sorghum flour, water and hydroxypropylmethylcellulose, found the dough quality to depend significantly on the three factors in a linear way. Specific volume, in particular, increased significantly with increasing proportions of corn starch/sorghum flour and hydroxypropylmethylcellulose. The crumb grain depended significantly on the three factors, their scorings increasing with corn starch/sorghum flour proportions and decreasing with water addition. Finally, a ratio of 0.55 corn starch/sorghum flour, 90\% water and 3\% hydroxypropylmethylcellulose was chosen as the best conditions, taking into account the acceptable levels of specific volume and crumb texture, as well as the possibility of using the highest proportion of sorghum flour.

Researches have been found in the literature that report spaghetti manufacture using flour mixtures, such as corn flour and rice flour, with the addition of an oat hydrocolloid ( $\beta$-glucan) called Nutrim-5, which makes it possible to produce spaghetti using $50 \%$ rice flour, and finding no differences in taste as compared to the control (100\% corn flour) [83].

Sabbatini [73], studied the effect of hydrocolloids in the formulation of a premixture for gluten-free noodles using as base ingredients: corn starch, cassava starch and rice flour. As regards machinability, guar gum showed the best performance, giving a dough easily framed and without stickiness. Regarding texture, guar gum also turned out to show the best quality, thus giving cooked noodles the typical characteristic of al dente consistency. As shown in Figure 3, these noodles resembled those made with wheat flour to a great extent.

Kaur et al. [84], studied the effects of glycerolmonoestearate (GMS) on the physicochemical, rheological and textural properties of noodles made with corn starch and potato starch. Noodles added with GMS showed longer cooking time and lower weight of the cooked noodles. Texture of cooked noodles was slightly softer, though with a higher cohesivity than the control ones.

On the other hand, formulations containing a mixture of $0.5 \%$ guar gum, $1 \%$ casein and $1 \%$ egg white were

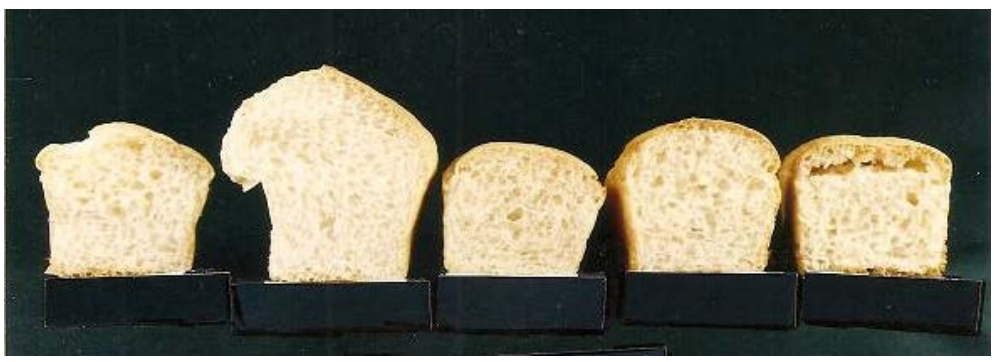

(a)

(b)

(c)

(d)

(e)

Figure 2. Gluten-free breads with different types of 2\% gums: (a) Guar; (b) hydroxypropylmethylcellulose; (c) Xantic; (d) Carboxymethylcellulose; (e) Espina Corona.

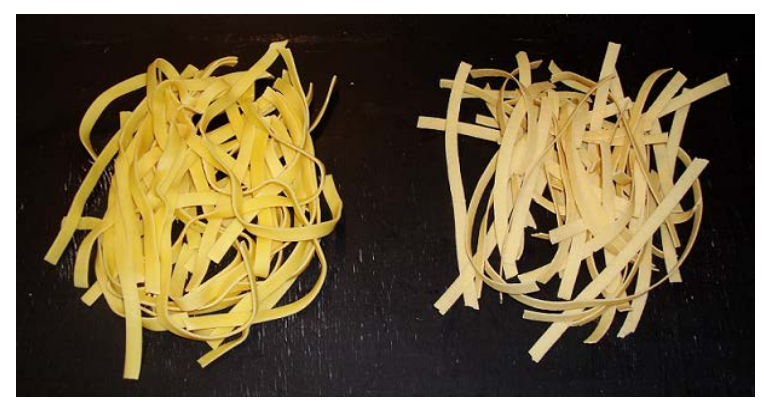

(a)

(b)

Figure 3. Noodles: (a) with wheat flour; (b) gluten-free. 
used. Nonpregelatinized rice semolina was also mixed with pregelatinized rice semolina in different proportions ( $0 \%, 25 \%, 50 \%, 75 \%$ and $100 \%)$. The effects of gelatinization, gums and proteins on dough rheology were determined by a rheometer. Data evidenced that, as the proportion of pregelatinized rice semolina increased, the dough elasticity increased. However, a smooth and soft to palate texture was not found in samples containing 75 and $100 \%$ of pregelatinized rice. Moreover, it was demonstrated that guar gum and the mix of proteins could be used as a stabilizer of the formulation containing $50 \%$ of pregelatinized rice semolina [85].

Another study was designed to analyze the effects of adding gums, whey protein concentrate, egg powder and water to corn and cassava starches in the rheological properties of a non-fermented dough for the manufacture of "empanadas" dough. Viscoelastic measurements and texture analysis were carried out. The increase in gum content and a decrease in water amount resulted in a more elastic dough. On the other hand, a higher proportion of proteins is known to interfere with the formation of the three-dimensional network formed by hydrocolloids, which makes the dough less ductile. Formulations containing higher percentages of gums and less water content lead to an appropriate behaviour for the industrial production of these doughs [86].

\subsection{Soy Flour}

The high allergenicity of soya (Glycine max L.) and the associated digestive problems are leading to more research into alternative protein sources, which may be able to provide gas-holding capacity and bake development. Legumes are important sources of food proteins with high content of lysine, leucine, aspartic acid, glutamic acid and arginine and they provide well balanced essential amino acid profiles when consumed with cereals and other foods rich in sulphur containing amino acids and tryptophan. Apart from their nutritional properties, legume proteins also possess functional properties that play an important role in food formulation and processing [2]. One of their most important properties is solubility, which is affected by $\mathrm{pH}$, heat and other factors. Heat treatment denatures soy proteins, thereby decreasing their solubility. Foam-forming and gel-forming capacity, under certain conditions, is also some of their attributes [87]. These proteins can be found in flours, concentrates, isolates and in texturized products; being suitable to meet human requirements only if correctly processed.

The 70/30 corn/soybean ratio is being used in different places of the world for flour mixtures, as a result of computerized programs that determine an optimum composition based on the amino acid content of different sources. Considering that the so-called "social interest foods" point at a food product of high nutritional value that can be used in traditional dishes without creating new food habits, this requirement is met by this type of flours.

Soybean is a very nutritious legume containing a high percentage of high quality proteins (about $37 \%$ ), with almost all the essential amino acids but one, methionine. Weight for weight, soy contains twice the proteins of meat, four times the egg protein and twelve times the milk protein. It also has $18 \%$ of unsaturated fats, vitamin $\mathrm{A}, \mathrm{E}$ and $\mathrm{K}$, and those of the $\mathrm{B}$ group (thiamine, riboflavin and niacin). It contains a large amount of minerals like phosphorus, calcium, magnesium, iron and copper, and is one of the richest sources of lecithin, essential for living cells, since it emulsifies cholesterol and helps in the assimilation of vitamins.

\subsection{Dairy Products}

About $90 \%$ of milk used in the cheese industry is eliminated as whey, which retains $55 \%$ of total milk ingredients such as lactose, soluble proteins, lipids and mineral salts. A significant portion of this residue is discarded as effluent, which raises a serious environmental issue since it affects the soil structure, leading to a decreased culture yield and depleting the dissolved oxygen in the waterways [88].

The use of dairy powder in gluten-free baked product formulations has resulted in improved volume as well as better appearance and sensory aspects of the loaves; the most used ingredients in gluten-free baked product formulations are caseinates, skim milk powder, dry protein concentrate and milk protein isolate [89].

Whey protein concentrate (WPC) is a by-product of cheese making, where the insoluble proteins composing the main product are separated from the soluble ones, which form the whey, with about $90 \%$ of water. By means of techniques such as ultrafiltration, this whey becomes whey protein concentrate, which is used by several food industries [90]. Both, cheese whey concentrates and isolates, have from $35 \%$ to $90 \%$ protein [91], and are used as ingredients in foods due to some of their functional properties [90].

As regards whey protein quality, it is known to be closely related to its nutritional and functional properties. 
Nutritional properties are determined by an adequate amino acid composition and balance, since several of them are essential ones, like lysine and tryptophan, and it also has sulfur amino acids, which give them a very high biological value. Functional properties, on the other hand, are those that confer foods some distinctive characteristics of appearance, texture, taste, and so on, when using whey as ingredient. The functional properties of the different protein wheys, concentrates and isolates are countless: emulsifying capacity, substitution of milk fat in diet products, solubility, aeration, colour and taste development, water binder, viscosity and solubility, among others [92].

WPC containing $35 \%$ protein are used as skim milk substitutes in the manufacture of yoghurt, processed cheeses, drinks, sauces, ice cream, spaghetti, cookies, bakery products and infant formulations, due to the excellent functional properties of their proteins and their nutritional benefits [91].

Sánchez et al. [26], working with soy flour and milk powder in variable amounts, found that a gluten-free bread can be prepared incorporating $7.5 \%$ of soy flour and $7.8 \%$ of milk powder, thus increasing its protein content from $1 \%$ to $7.3 \%$ with a minimum alteration of its sensory characteristics.

Sabbatini [73], carried out noodles protein fortification by incorporating ingredients rich in proteins of high biological value, which, apart from increasing the total protein content, also allowed improving the food essential amino acid composition. Aiming at improving the nutritional value of gluten-free noodles, they added commercial soy flour (Low Fat Soy Flour-LFSF) and whey protein concentrate (WPC) to the formulation during the fortification step. The simultaneous consumption of cereals and oilseeds in the same food increases protein quality due to the amino acid complementation [93]. As regards solid loss during cooking, in all cases it was found to be much higher with the addition of LFSF than with WPC. When comparing this parameter in wheat flourbased noodles (2.3\%) with the gluten-free ones fortified with 10\% WPC and 10\% LFSF (1.87\%), solid loss was observed to be higher, in average, for wheat based noodles. The same stands for the optimum cooking time, since solid loss for control noodles turned out to be $0.4 \%$, whereas the figure was $8.5 \%$ for gluten-free formulation. Considering noodles texture evaluation, both WPC and LFSF produced a consistency increase in noodles when increasing the proportion in which they were added to the premixture, thus leading to a good texture even in high percentages. This fact coincides with that of Del Nobile et al. [94], who found that increasing the protein content of pasta resulted in a higher firmness. As regards taste, the noodles proved acceptable from the sensory viewpoint when WPC and LFSF were added simultaneously, in the same proportions, to the base mixture. Conversely, taste lost acceptability when the soybean flour proportion was higher than that of whey protein concentrate.

\section{References}

[1] Heredia, C., Castro, F. andPalma, J. (2007) Adult Celiac Disease. Revista Médica de Chile, 135, 1186-1194.

[2] Miñarro, B., Albanell, E., Aguilar, N., Guamis, B. and Capellas, M. (2012) Effect of Legume Flours on Baking Characteristics of Gluten-Free Bread. Journal of Cereal Science, 56, 476-481. http://dx.doi.org/10.1016/j.jcs.2012.04.012

[3] Kawamura-Konishi, Y., Shoda, K., Koga, H. and Honda, Y. (2013) Improvement in Gluten-Free Rice Bread Quality by Protease Treatment. Journal of Cereal Science, 58, 45-50. http://dx.doi.org/10.1016/j.jcs.2013.02.010

[4] Murray, J.A. (1999) The Widening Spectrum of Celiac Disease. American Journal of Clinical Nutrition, 69, $354-365$.

[5] Tsatsaragkou, K., Yiannopoulos, S., Kontogiorgi, A., Poulli, E., Krokida, M. and Mandala, I. (2012) Mathematical Approach of Structural and Textural Properties of Gluten Free Bread Enriched with Carob Flour. Journal of Cereal Science, 56, 603-609. http://dx.doi.org/10.1016/j.jcs.2012.07.007

[6] Huang, X., Kanerva, P., Salovaara, H., Loponen, J. and Sontag-Strohm, T. (2013) Oxidative Modification of a Proline-Rich Gliadin Peptide. Food Chemistry, 141, 2011-2016. http://dx.doi.org/10.1016/j.foodchem.2013.05.066

[7] Cosnes, J., Cellier, C., Viola, S., Colombel, J.F., Michaud Sarles, J.L., Hugot, J.P., Ginies, J.L., Dabadie, A., Mouterde, O., Allez, M. andNion-Larmurier, I. (2008) Incidence of Autoinmune Diseases in Celiac Disease: Protective Effect of the Gluten-Free Diet. Clinical Gastroenterology, 7, 753-758. http://dx.doi.org/10.1016/j.cgh.2007.12.022

[8] Albanell, E., Miñarro, B. and Carrasco, N. (2012) Detection of Low-Level Gluten Content in Flour and Batter by near Infrared Reflectance Spectroscopy (NIRS). Journal of Cereal Science, 56, 490-495. http://dx.doi.org/10.1016/j.jcs.2012.06.011

[9] Canales, P., Araya, M., Alliende, F., Hunter, B., Alarcón, T. and Chávez, E. (2008) Diagnosis and Clinical Presentations of Celiac Disease. A Multicenter Study. Revista Médica de Chile, 136, 296-303.

[10] Londono, D.M., van’t Westende, W.P.C., Goryunova, S., Salentijn, E.M.J., van den Broeck, H.C., van der Meer, I.M., 
Visser, R.G.F., Gilissen, L.J.W. and Smulders, M.J.M. (2013) Avenin Diversity Analysis of the Genus Avena (Oat). Relevance for People with Celiac Disease. Journal of Cereal Science, 58, 170-177. http://dx.doi.org/10.1016/j.jcs.2013.03.017

[11] Hernández, G. and Argüelles, H. (2006) Manejo nutricional de la enfermedad celíaca. Revista Cubana de Pediatría, 78, 1-7.

[12] Bai, J., Zeballos, E. and Fried, M. (2005) Practice Guidelines: Celiac Disease. World Gastroenterology News, 10, 1-8.

[13] Cammarota, G., Cuoco, L., Cianci, R., Pandolfi, F. and Gasbarrini, G. (2000) Onset of Coeliac Disease during Treatment with Interferon for Chronic Hepatitis C. The Lancet, 356, 1494-1495. http://dx.doi.org/10.1016/S0140-6736(00)02880-4

[14] Di Sabatino, A. and Corazza, G. (2009) Coeliac Disease. The Lancet, 373, 1480-1493. http://dx.doi.org/10.1016/S0140-6736(09)60254-3

[15] De Vita, P., Ficco, D.B.M., Luciani, A., Vincentini, O., Pettoello-Mantovani, M., Silano, M., Maiuri, L. and Cattivelli, L. (2012) A $\omega$-Secalin Contained Decamer Shows a Celiac Disease Prevention Activity. Journal of Cereal Science, 55, 234-242. http://dx.doi.org/10.1016/j.jcs.2011.12.006

[16] Kelly, C.P., Feighery, C., Gallagher, R.B. and Weir, D.G. (1999) The Diagnosis and Treatment of Gluten-Sensitive Enteropathy. Advances in Internal Medicine, 35, 341-364.

[17] Guevara, G. (2002) Enfermedad Celíaca. Revista Chilena de Pedriatría, 73, 394-397. http://dx.doi.org/10.4067/S0370-41062002000400012

[18] Araya, M. (2006) Improving the Management of Celiac Disease. An Urgent Challenge. Revista Médica de Chile, 134, 361-364.

[19] Mitre, M.B. (2004) Enfermedad Celíaca. http://www.intramed. net/UserFiles/Files/celiaco.pdf

[20] Green, P. and Jabri, B. (2003) Coeliac Disease. The Lancet, 362, 383-391. http://dx.doi.org/10.1016/S0140-6736(03)14027-5

[21] Fasano, A. and Catassi, C. (2001) Current Approaches to Diagnosis and Treatment of Celiac Disease: An Evolving Spectrum. Gastroenterology, 120, 636-651. http://dx.doi.org/10.1053/gast.2001.22123

[22] Kennedy, N.P. and Feighery, C. (2000) Clinical Features of Coeliac Disease Today. Biomedicine and Pharmacotherapy, 54, 373-380. http://dx.doi.org/10.1016/S0753-3322(01)80004-4

[23] Sanchez, H.D., Osella, C.A. and de la Torre, M.A. (1996) Desarrollo de una fórmula para pan sin gluten. Información Tecnológica, 7, 35-42.

[24] Sánchez, H.D., González, R.J., Osella, C.A., Torres, R.L. and de la Torre, M.A. (2008) Elaboración de pan sin gluten con harinas de arroz extrudidas. Ciencia y Tecnología Alimentaria, 6, 109-116. http://dx.doi.org/10.1080/11358120809487635

[25] Sanchez, H.D., Osella, C.A. and de la Torre, M.A. (2002) Optimization of Gluten-Free Bread Prepared from Cornstarch, Rice Flour, and Cassava Starch. Journal of Food Science, 67, 416-419. http://dx.doi.org/10.1111/j.1365-2621.2002.tb11420.x

[26] Sánchez, H.D., Osella, C.A. and de la Torre, M.A. (2004) Use of Response Surface Methodology to Optimize GlutenFree Bread Fortified with Soy Flour and Dry Milk. Food Science and Technology International, 10, 5-9. http://dx.doi.org/10.1177/1082013204042067

[27] Croft, N.M. (2008) Gluten-Free Diets in Celiac Disease: Does Life Mean Life. Gastroenterology, 134, 883-885. http://dx.doi.org/10.1053/j.gastro.2008.01.048

[28] Al-Toma, A., Verbeek, W.H. and Mulder, C.J. (2007) Update on the Management of Refractory Coeliac Disease. Journal of Gastrointestin and Liver Disesases, 16, 57-63.

[29] Krauss, N. and Schuppan, D. (2006) RETRACTED: Monitoring Nonresponsive Patients Who Have Celiac Disease. Gastrointestinal Endoscopy Clinics of North America, 16, 317-327. http://dx.doi.org/10.1016/j.giec.2006.03.005

[30] Raymond, N., Heap, J. and Case, S. (2006) The Gluten-Free Diet: An Update for Health Professionals. Practical Gastroenterology, 30, 67-92.

[31] Green, P., Stavropoulos, S.N., Panagi, S., Glodstein, S.L., Mc Mahon, D., Absan, H. and Neugut, A. (2001) Characteristic of Adult Celiac Disease in the USA: Results of a National Survey. American Journal of Gastroenterology, 96, 126131. http://dx.doi.org/10.1111/j.1572-0241.2001.03462.x

[32] Case, S. (2005) The Gluten-Free Diet: How to Provide Effective Education and Resources. Gastroenterology, 128, S128S134. http://dx.doi.org/10.1053/j.gastro.2005.02.020

[33] Niewinski, M.M. (2008) Advances in Celiac Disease and Gluten-Free Diet. Journal of the American Dietetic Association, 108, 661-672. http://dx.doi.org/10.1016/j.jada.2008.01.011 
[34] Gibert, A., Espadaler, A. and Montserrat, A. (2006) Consumption of Gluten-Free Products: Should the Threshold Value for Trace Amounts of Gluten be at 20, 100 or 200 ppm.? European Journal of Gastroenterology and Hepatology, 18, 1187-1195. http://dx.doi.org/10.1097/01.meg.0000236884.21343.e4

[35] Alvarez, P.A., Mongeon, V.J. and Boye, J.I. (2013) Characterization of a Gluten Reference Material: Wheat-Contaminated Oats. Journal of Cereal Science, 57, 418-423. http://dx.doi.org/10.1016/j.jcs.2013.01.006

[36] Akobeng, A.K. and Thomas, A.G. (2008) Systematic Review: Tolerable Amount of Gluten for People with Coeliac Disease. Alimentary Pharmacology and Therapeutics, 27, 1044-1152. http://dx.doi.org/10.1111/j.1365-2036.2008.03669.x

[37] Lester, D.R. (2008) Gluten Measurement and Its Relationship to Food Toxicity for Celiac Disease Patients. Plant Methods, 4, 26-30. http://dx.doi.org/10.1186/1746-4811-4-26

[38] Denery-Papini, S., Nicolas, Y. and Popineau, Y. (1999) Efficiency and Limitations of Immunochemical Assays for Testing of Gluten-Free Foods. Journal of Cereal Science, 30, 121-131. http://dx.doi.org/10.1006/jcrs.1999.0268

[39] van Heel, D.A. and West, J. (2006) Recent Advances in Coeliac Disease. Gut, 55, 1037-1046. http://dx.doi.org/10.1136/gut.2005.075119

[40] Wang, J.S., Zhao, M.M., Zhao, Q.Z., Bao, Y. and Jiang, Y.M. (2007) Characterization of Hydrolizates Derives from Enzymatic Hydrolysis of Wheat Gluten. Journal of Food Science, 72, 103-107. http://dx.doi.org/10.1111/j.1750-3841.2006.00247.x

[41] Del Castillo, V., Lescano, G. and Armada, M. (2009) Formulación de alimentos para celíacos con base en mezclas de harinas de quínoa, cereales y almidones. Archivos Latinoamericanos de Nutrición, 59, 332-336.

[42] Padalino, L., Mastromatteo, M., Lecce, L., Cozzolino, F. and Del Nobile, M.A. (2013) Manufacture and Characterization of Gluten-Free Spaghetti Enriched with Vegetable Flour. Journal of Cereal Science, 57, 333-342. http://dx.doi.org/10.1016/j.jcs.2012.12.010

[43] Kohlwey, D.E., Kendall, J.H. and Mohindra, R.B. (1995) Using the Physical Properties of Rice as a Guide to Formulation. Cereal Foods World, 40, 728-732.

[44] Gallagher, E., Gormley, T.R. and Arendt, E.K. (2004) Review Recent Advances in the Formulation of Gluten-Free CerealBased Products. Trends in Food Science and Technology, 15, 143-152. http://dx.doi.org/10.1016/j.tifs.2003.09.012

[45] Anton, A. and Artfield, S. (2008) Hydrocolloids in Gluten-Free Breads: A Review. International Journal of Food Sciences and Nutrition, 59, 11-23. http://dx.doi.org/10.1080/09637480701625630

[46] Lazaridou, A., Duta, D., Papageorgiou, M., Belc, N. and Biliaderis, C.G. (2007) Effects of Hydrocolloids on Dough Rheology and Bread Quality Parameters in Gluten-Free Formulations. Journal of Food Engineering, 79, 1033-1047. http://dx.doi.org/10.1016/j.jfoodeng.2006.03.032

[47] Demirkesen, L., Mert, B., Sumnu, G. and Sahin, S. (2010) Rheological Properties of Gluten-Free Bread Formulations. Journal of Food Engineering, 96, 295-303. http://dx.doi.org/10.1016/j.jfoodeng.2009.08.004

[48] Limroongreungrat, K. and Huang, Y.W. (2007) Pasta Products Made from Sweetpotato Fortified with Soy Protein. LWT-Food Science and Technology, 40, 200-206. http://dx.doi.org/10.1016/j.lwt.2005.09.012

[49] Sienkiewicz, T. and Riedel, C.L. (1990) Utilization of Whey. Whey and Whey Utilization, Ed. Verlag Th. Mann, Gelsenkirchen, 215.

[50] FAO (2004) El Arroz y la Nutrición Humana. http://www.fao.org/rice2004/es/f-sheet/hoja3.pdf

[51] Phimolsiripol, Y., Mukprasirt, A. and Schoenlechner, R. (2012) Quality Improvement of Rice-Based Gluten-Free Bread Using Different Dietary Fibre Fractions of Rice Bran. Journal of Cereal Science, 56, 389-395. http://dx.doi.org/10.1016/j.jcs.2012.06.001

[52] Hamada, S., Suzuki, K., Aoki, N. and Suzuki, Y. (2013) Improvements in the Qualities of Gluten-Free Bread after Using a Protease Obtained from Aspergillus oryzae. Journal of Cereal Science, 57, 91-97. http://dx.doi.org/10.1016/j.jcs.2012.10.008

[53] Torres, R.L., González, R.J., Sánchez, H.D., Osella, C.A. and de la Torre, M.A. (1999) Comportamiento de variedades de arroz en la elaboración de pan sin gluten. Archivos Latinoamericanos de Nutrición, 49, 162-165.

[54] Athapol, N., Ngamchuen, K. and Muanmai, A. (1997) Effect of Aging on the Quality of Glutinous Rice Crackers. Cereal Chemistry, 74, 12-15. http://dx.doi.org/10.1094/CCHEM.1997.74.1.12

[55] Sivaramakrishnan, H.P., Senge, B. and Chattopadhyay, P.K. (2004) Rheological Properties of Rice Dough for Making Rice Bread. Journal of Food Engineering, 62, 37-45. http://dx.doi.org/10.1016/S0260-8774(03)00169-9

[56] Sheng, D.Y. (1995) Rice-Based Ingredients in Cereals and Snacks. Cereal Foods World, 40, 538-540.

[57] González, R.J., Torres, R.L. and de Greef, D.M. (2002) Extrusión-Cocción de cereales. Boletín da Sociedade Brasileira de Ciencia e Tecnología de Alimentos, Campinas, 36, 83-136. 
[58] Gonzalez, R.J., Torres, R.L. and De Greef, D.M. (1998) Comportamiento a la cocción de variedades de arroz y maíz utilizando el amilógrafo y dos diseños de extrusores. Información Tecnológica, 9, 35-43.

[59] Gonzalez, R.J., Torres, R.L. and Añón, M.C. (2000) Comparison of Rice and Corn Cooking Characteristics before and after Extrusion. Polish Journal of Food and Nutrition Sciences, 50, 29-34.

[60] González, R.J., Torres, R.L. and De Greef, D.M. (2006) El arroz como alimento. El grano y la harina. Parámetros de caracterización y de calidad. El arroz. Su cultivo y sustentabilidad en Entre Ríos, Editorial de la UNER y UNL, 1, Cap. 1.

[61] Pedrosa Silva, M.T. and El-Dash, A. (2006) Farinha extrusada de arroz como substituto de gluten na producao de pao de arroz. Archivos Latinoamericanos de Nutrición, 56, 288-299.

[62] Schober, T.J., Messerschmidt, M., Bean, S.R., Park, S.H. and Arendt, E.K. (2005) Gluten-Free Bread from Sorghum: Quality Differences among Hybrids. Cereal Chemistry, 82, 394-404. http://dx.doi.org/10.1094/CC-82-0394

[63] Awika, J.M. and Rooney, L.W. (2004) Sorghum Phytochemicals and Their Potential Impacton Human Health. Phytochemistry, 65, 1199-1221. http://dx.doi.org/10.1016/j.phytochem.2004.04.001

[64] Ciacci, C., Maiuri, L., Caporaso, N., Bucci, C., Del Giudice, L., Massardo, D.R., Pontieri, P., Di Fonzo, N., Bean, S.R., Ioerger, B. and Londei, M. (2007) Celiac Disease: In Vitro and in Vivo Safety and Palatability of Wheat-Free Sorghum Food Products. Clinical Nutrition, 26, 799-805. http://dx.doi.org/10.1016/j.clnu.2007.05.006

[65] Liu, L., Herald, T.J., Wang, D., Wilson, J.D., Bean, S.R. and Aramoun, F.M. (2012) Characterization of Sorghum Grain and Evaluation of Sorghum Flour in a Chinese Egg Noodle System. Journal of Cereal Science, 55, 31-36. http://dx.doi.org/10.1016/j.jcs.2011.09.007

[66] Taylor, J.R.N., Schober, T.J. and Bean, S.R. (2006) Novel Food and Non-Food Uses for Sorghum and Millets. Journal of Cereal Science, 44, 252-271. http://dx.doi.org/10.1016/j.jcs.2006.06.009

[67] Onyango, C., Mutungi, C., Unbehend, G. and Lindhauer, M.G. (2011) Modification of Gluten-Free Sorghum Batter and Bread Using Maize, Potato, Cassava or Rice Starch. LWT-Food Science and Technology, 44, 681-686.

[68] Keregero, M.M. and Mtebe, K. (1994) Acceptability of Wheat-Sorghum Composite Flour Products: An Assessment. Plant Foods for Human Nutrition, 46, 305-312. http://dx.doi.org/10.1007/BF01088429

[69] Schober, T.J., Bean, S.R. and Boyle, D.L.J. (2007) Gluten-Free Sorghum Bread Improved by Sourdough Fermentation: Biochemical, Rheological, and Microstructural Background. Journal of Agricultural and Food Chemistry, 55, 51375146. http://dx.doi.org/10.1021/jf0704155

[70] Aristizábal, J. and Sánchez, T. (2007) Características del Almidón de Yuca. http://www.fao.org/docrep/010/a1028s/a1028s00.HTM

[71] Singh, N., Kaur, L., Sodhi, N.S. and Sekhon, K. (2005) Physicochemical, Cooking and Textural Properties of Miled Rice from Different Indian Rice Cultivars. Food Chemistry, 89, 253-259. http://dx.doi.org/10.1016/j.foodchem.2004.02.032

[72] Pérez, L. (2007) Elaboración de pasta alimenticia por sustitución de sémola de trigo por harina de yuca 10, 15, 20\% y zumo de remolacha. Tesis de Licenciatura, Escuela de Biología, Facultad de Ciencias, Universidad Central de Venezuela.

[73] Sabbatini, S. (2011) Formulación de una premezcla "sin gluten” para la elaboración de fideos tipo cinta, fortificados con harina de soja y concentrado proteico de suero caseario. Tesis Maestría en Ciencia y Tecnología de Alimentos, Facultad de Ingeniería Química, Universidad Nacional del Litoral, Santa Fe.

[74] Barrios, S.E., Contreras, J.M. and López Carrasquero, F. (2009) Estudio preliminar de modificación química de almidón de yuca mediante reacciones de carboximetilación asistida por microondas. Suplemento de la Revista Latinoamericana de Metalurgia y Materiales, S2, 159-160.

[75] Marconi, E. and Carcea, M. (2001) Pasta from No-Traditional Raw Materials. Cereal Foods World, 46, 522-530.

[76] Norton, I.T. and Foster, T.J. (2002) Hydrocolloids in Real Food Systems. In: Williams, P.A. and Phillips, G.O., Eds., Gums and Stabilizers in the Food Industry 11, Thomas Graham House, Cambridge, 187-200.

[77] Hoefler, A.C. (2004) Functions and Properties. Hydrocolloids, Eagan Press Ed. American Association of Cereal Chemist. St. Paul, Minesota, 27-41.

[78] Schwarzlaff, S.S., Johnson, J.M., Barbeau, W.E. and Duncan, S. (1996) Guar and Locust Bean Gums as Partial Replaces of All-Purpose Flour in Bread: An Objective and Sensory Evaluation. Journal of Food Quality, 19, 217-229. http://dx.doi.org/10.1111/j.1745-4557.1996.tb00417.x

[79] Susanna, S. and Prabhasankar, P. (2013) A Study on Development of Gluten Free Pasta and Its Biochemical and Immunological Validation. LWT-Food Science and Technology, 50, 613-621.

[80] Moreira, R., Chenlo, F. and Torres, M.D. (2013) Effect of Chia (Sativa hispanica L.) and Hydrocolloids on the Rheology of Gluten-Free Doughs Based on Chestnut Flour. LWT-Food Science and Technology, 50, 160-166.

[81] Anton, A. and Artfield, S. (2008) Hydrocolloids in Gluten-Free Breads: A Review. International Journal of Food Sciences 
and Nutrition, 59, 11-23. http://dx.doi.org/10.1080/09637480701625630

[82] Velázquez, N., Sánchez, H.D., Osella, C. and Santiago, L. (2012) Using White Sorghum Flour for Gluten-Free Breadmaking. International Journal of Food Sciences and Nutrition, 63, 491-497. http://dx.doi.org/10.3109/09637486.2011.636734

[83] Inglett, G.E., Peterson, S.C., Carriere, C.J. and Maneepun, S. (2005) Rheological, Textural and Sensory Properties of Asian Noodles Containing an Oat Cereal Hydrocolloid. Food Chemistry, 90, 1-8. http://dx.doi.org/10.1016/j.foodchem.2003.08.023

[84] Kaur, C.P., Sing, J. and Sing, N. (2005) Effect of Glycerol Monoestearate on the Physico-Chemical, Thermal, Rheological and Noodle Making Properties of Corn and Potato Starches. Food Hydrocolloids, 19, 839-849. http://dx.doi.org/10.1016/j.foodhyd.2004.10.036

[85] Sozer, N. (2009) Rheological Properties of Rice Pasta Dough Supplemented with Proteins and Gums. Food Hydrocolloids, 23, 849-855. http://dx.doi.org/10.1016/j.foodhyd.2008.03.016

[86] Lorenzo, G., Zaritzky, N.E. and Califano, A.N. (2008) Optimization of Non-Fermented Gluten-Free Dough Composition Based on Rheological Behavior for Industrial Production of "Empanadas" and Pie-Crusts. Journal of Cereal Science, 48, 224-231. http://dx.doi.org/10.1016/j.jcs.2007.09.003

[87] Luna Jiménez, A. (2006) Valor nutritivo de la proteína de soya. Revista Investigación y Ciencia, Universidad de Aguas Calientes, Mexico, 14, 29-34.

[88] Aider, M., Haleux, D. and Melnikova, I. (2009) Skim Acidic Milk Whey Cryoconcentration and Assessment of Its Functional Properties: Impact of Processing Conditions. Innovative Food Science and Emerging Technologies, 10, 334-341. http://dx.doi.org/10.1016/j.ifset.2009.01.005

[89] Storck, C.R., da Rosa Zavareze, E., Gularte, M.A., Cardoso Elias, M., Molina Rosell, C.A. and Guerra Dias, R. (2013) Protein Enrichment and Its Effects on Gluten-Free Bread Characteristics. LWT-Food Science and Technology, 53, 346354.

[90] Visentín, A.N., Drago, S.R., Osella, C.A., de la Torre, M.A., Sánchez, H.D. and González, R.J. (2009) Efecto de la adición de harina de soja y concentrado proteico de suero de queso sobre la calidad del pan y la dializabilidad de los minerales. Archivos Latinoamericanos de Nutrición, 59, 325-331.

[91] Parra Huertas, R.A. (2009) Lactosuero: Importancia en la industria de alimentos. Revista Facultad Nacional de Agronomía, Medellín, 62, 4967-4982.

[92] Schaller, A. (2008) Sueros de lechería. Cadenas Alimentarias. http://www.alimentosargentinos.gov.ar/0-3/r_44/cadenas/Lacteos.html

[93] Baiano, A., Lamacchia, C., Fares, C., Terracone, C. and La Notte, E. (2011) Cooking Behaviour and Acceptability of Composite Pasta Made of Semolina and Toasted or Partially Defatted Soy Flour. LWT-Food Science and Technology, 44, 12261232.

[94] Del Nobile, M.A., Baiano, A., Conte, A. and Mocci, G. (2005) Influence of Protein Content on Spaghetti Cooking Quality. Journal of Cereal Science, 41, 347-356. http://dx.doi.org/10.1016/j.jcs.2004.12.003 